\title{
MAO-inhibitors in Parkinson's Disease
}

\author{
Peter Riederer ${ }^{1} *$ and Gerd Laux ${ }^{2}$ \\ ${ }^{1}$ Clinic and Policlinic for Psychiatry, Psychosomatic and Psychotherapy, \\ University of Wuerzburg, 97080 Wuerzburg, \\ ${ }^{2}$ Academic Hospital of Psychiatry, Psychosomatic Medicine, Psychotherapy and \\ Neurology, Gabersee, 83512 Wasserburg a. Inn, Germany
}

\begin{abstract}
Monoamine oxidase inhibitors (MAO-I) belong to the earliest drugs tried in Parkinson's disease (PD). They have been used with or without levodopa (L-DOPA). Non-selective MAO-I due to their side-effect/adverse reaction profile, like tranylcypromine have limited use in the treatment of depression in PD, while selective, reversible MAO-A inhibitors are recommended due to their easier clinical handling. For the treatment of akinesia and motor fluctuations selective irreversible MAO-B inhibitors selegiline and rasagiline are recommended. They are safe and well tolerated at the recommended daily doses. Their main differences are related to (1) metabolism, (2) interaction with CYP-enzymes and (3) quantitative properties at the molecular biological/genetic level. Rasagiline is more potent in clinical practise and has a hypothesis driven more favourable side effect/adverse reaction profile due to its metabolism to aminoindan. Both selegiline and rasagiline have a neuroprotective and neurorestaurative potential. A head-to head clinical trial would be of utmost interest from both the clinical outcome and a hypothesis-driven point of view. Selegiline is available as tablet and melting tablet for PD and as transdermal selegiline for depression, while rasagiline is marketed as tablet for PD. In general, the clinical use of MAO-I nowadays is underestimated. There should be more efforts to evaluate their clinical potency as antidepressants and antidementive drugs in addition to the final proof of their disease-modifying potential. In line with this are recent innovative developments of MAO-I plus inhibition of acetylcholine esterase for Alzheimer's disease as well as combined MAO-I and iron chelation for PD.
\end{abstract}

Key words: selegiline, rasagiline, moclobemide, phenelzine, tranylcypromine

\section{INTRODUCTION}

Monoamine oxidase (MAO) is an important enzyme to metabolize in vivo endogenous and diet-derived biogenic amines via oxidative deamination. Major

*To whom correspondence should be addressed.

TEL: 49-931-201-77200, FAX: 49-931-201-77220

e-mail: peter.riederer@mail.uni-wuerzburg.de

Received December 28, 2010

Accepted for publication January 17, 2011 substrates are noradrenaline, adrenaline, dopamine, $\beta$-phenylethylamine (PEA) and serotonin. These substrates are underlying in the biochemical pathology of "depression" and Parkinson's disease (PD). The deficiency of serotonin, noradrenaline and dopamine builds-up the hypothesis of "depression" while a loss of dopamine, noradrenaline and serotonin is the biochemical basis of degenerative processes underlying PD. Therefore, supplementation of deficient biogenic amine neurotransmitters with 3,4-dihydroxy- 
phenylalanin (L-DOPA) has been established as early as the late $50^{\text {th }}$ and early $60^{\text {th }}$ of the last century including the use of MAO-inhibitors. This class of psychopharmacological active compounds inhibits the break-down of biogenic amine neurotransmitters and thus increase their concentration in the synaptic cleft and at respective postsynaptic receptor sites. A mood elevating effect in patients with tuberculosis after treatment with iproniazid was first described by Kline (1958). In PD the first reports were published by Sano (1960; Foley et al., 2000) using iproniazid and pheniprazine alone or in combination with D,L-DOPA in a small number of patients, Degkwitz et al. (1960), who used iproniazid in combination with L-DOPA and in reserpin treated patients with schizophrenia and Birkmayer, Hornykiewicz and Bernheimer, who tried a variety of compounds like harmine, isocarboxazid and other MAO-l's (Bernheimer et al., 1961; Birkmayer and Hornykiewicz 1961 ; 1962; 1964) alone or in combination with LDOPA in PD. The effects were mild or not existing when these MAO-I were given alone. However all theses early reports agree that MAO-I potentiated the effect of (D), L-DOPA but intensified also adverse reactions. Further examination and post mortem studies gave evidence that MAO-I given shortly before patients deaths were restoring the levels of noradrenaline and serotonin with no significant effect on the concentration of brain dopamine (Bernheimer et al., 1962; 1963). This data pointed to a combination therapy of L-DOPA and MAO-I already in the early $60^{\text {th }}$ of the last century. An extensive description of detailed historical aspects of MAO and its inhibitors is given in the excellent overview on treatment strategies in PD by Foley (2001). A further break-through was the discovery of multiple forms of MAO, MAO-A and MAO-B, by Johnston (1968). MAO-A deaminates especially serotonin, noradrenaline and tyramine and is inhibited selectively at low concentrations $(\mu \mathrm{M})$ of clorgyline while MAO-B is insensitive to clorgyline and in the human brain desaminates PEA and to a high degree dopamine (Glover et al., 1977). The first selective MAO-B-I was L-deprenyl (E-250, L-deprenyl, selegiline), synthezised by Zoltan Ecseri in 1962, patented as antidepressant in 1965, 1966 and developed by Jozsef Knoll as "psychic energizer (Knoll et al., 1965)." The combination of selegilines selective MAO-B-I properties and the short-lasting stimulant effect of one of its metabolites, metamphetamine, (later proved to be also a reversible MAO-inhibitor see also Foley 2001 for details of such early developments) was indeed a concept to put forward new antidepressant agents (Varga and Tringer, 1967). Knoll mentioned in his 1965 publication that selegiline does not increase motility and lowers blood pressure in experimental animals. Using tyramine (a MAO-A and -B substrate) it became evident that selegiline antagonizes the socalled "cheese-effect" (increase of blood pressure noteable especially after consumption of larger amounts of cheese in patients treated with unselective or MAO-A-inhibitors) (Knoll and Magyar, 1972). As dopamine in rodent brain is $s$ preferred MAO-A substrate an effect of MAO-inhibitors on motility (see above) has not been observed. PD, therefore, was not the focus for using MAO-B-I as therapeutic strategy. The suggestion in late 1974 for selegilines use in PD and especially in treating ON-OFF symptoms by one of use (PR) was based on (1) the early and in principle beneficial effects of MAO-I when combined with L-DOPA (see above), (2) the effects of selegiline in antagonizing the cheeseeffect and (3) the possibility that dopamine in humans might well be a substrate for MAO-B. Convincing Moussa Youdim about using selegiline for a first trial in PD patients in PD he agreed to provide Walther Birkmayer and myself (P.R.) with some grams of selegiline that he had obtained from Josef Knoll. The trial was showing a beneficial effect in the symptomology of PD (Birkmayer et al., 1975; 1977; Foley, 2001; for historical notes see Riederer 2004; Youdim, 2006). Later (Birkmayer et al., 1983; 1985) we provided evidence for selegiline having neuroprotective action, a concept that is still followed and seems to be proven by the follow-up propargylaminoderivative rasagiline as shown recently in the ADAGIO-study (Olanow et al., 2008; 2009).

The innovating basic research and beneficial actions of selegiline in PD were responsible for intensive MAO-I drug developments for both PD and "depression". In this review we present the major compounds currently being used as well as an outlook of further such developments. 
Table 1. Monoamine oxidase inhibitors

\begin{tabular}{clcc}
\hline Drug & \multicolumn{1}{c}{ Metabolites } & Trials in humans & \multicolumn{1}{c}{ Galenic forms } \\
\hline Selegiline & Desmethylselegiline & AD, DEP, PD & Tablet, transdermal, melting tablet \\
& p-Hydroxydesmethylselegiline & & \\
& Selegiline-N-oxide & & \\
& L-Amphetamin & & \\
& L-Metamphetamin & & \\
& p-Hydroxyamphetamine & & \\
Rasagiline & Amydroxymetamphetamine & PD & Tablet \\
\hline
\end{tabular}

As reviewed by Magyar et al., 2010; Weinreb et al., 2010; Naoi and Maruyama, 2010.

\section{MAO-I in clinical practise}

Monoamine oxidase (MAO) inhibitors (MAOls) at present can be classified into 3 types:

- Older, irreversible nonselective agents such as phenelzine and tranylcypromine

- Irreversible, selective drugs (MAO-B-l's) such as selegiline and rasagiline

- Reversible, selective MAO-A inhibitors (RIMAs = reversible inhibitors of MAO-A) such as moclobemide (Overviews: Szelenyi 1993; Laux et al., 1995)

$\begin{array}{lr}\begin{array}{l}\text { Overview of } \\ \text { Iproniazid } \\ \text { Isocarboxazid } \\ \text { Moclobemide }\end{array} & \begin{array}{r}\text { Non-selective, irreversible } \\ \text { Non-selective, irreversible } \\ \text { MAO-A selective, } \\ \text { reversible (RIMA) }\end{array} \\ \begin{array}{l}\text { Nialamide } \\ \text { Pargyline }\end{array} & \begin{array}{r}\text { Non-selective, irreversible } \\ \text { Phenelzine }\end{array} \\ \text { Rasagiline } & \text { Non-selective, irreversible } \\ \text { Safrazine } & \text { MAO-B selective, irreversible } \\ \text { Selegiline } & \text { Non-selective, irreversible } \\ \text { Toloxatone } & \text { MAO-B selective, irreversible } \\ \text { MAO-A selective, } \\ \text { Tranylcypromine }\end{array} \quad \begin{array}{r}\text { reversible (RIMA) } \\ \text { Non-selective, irreversible }\end{array}$

The clinical indications and efficacy of the MAOls are established for disorders as follows:

- Parkinson's disease (PD)

- Depressive disorders

- Anxiety disorders (social phobia, panic disorder, PTSD)

Other potential therapeutic uses and indications can be smoking cessation, attention deficit hyper- activity disorder and cognitive deficits in dementia for moclobemide (Chan-Palay, 1992; Berlin et al., 1995).

\section{INDICATIONS IN PARKINSON'S DISEASE}

\section{Treatment of motor symptoms}

Both, selegiline and rasagiline (Table 1) are beneficial in treating motor symptoms in PD as monotherapy and in combination with L-DOPA and a decarboxylase inhibitor. Rasagiline is more effective in this regard as shown also in the daily dosis necessary for a symptomatic effect: $5 \sim 10 \mathrm{mg} /$ day selegiline, $1 \mathrm{mg} /$ day rasagiline. Long-term trials with selegiline point to the fact that $30 \sim 40 \%$ of the daily L-DOPA dosis can be spared when combined with the MAO-B-I (Szeleny, 1993; Lees et al., 1995; Myllylä et al., 1997). It is not far-fetched to assume, that PEA, which increases after selegiline treatment in brain tissue (Reynolds et al., 1978) and by this exerts dopamine release-promoting properties, contributes to dopamine's behavioural effects including improvement of motility (Foley, 2001; Gerlach et al., 2007; Riederer, 2009).

There is overwhelming evidence that selegiline has beneficial effects on motoricity and motorfluctuations as shown already in the first clinical trial (Birkmayer et al., 1975) and in follow-up clinical studies as summarized by Gerlach et al. (2007).

Rasagiline effects on motoricity are even stronger as shown by the TEMPO-(Parkinson Study Group, 2002; 2004), PRESTO- (Parkinson-Study-Group, 2005), LARGO- (Rascol et al., 2005) and ADAGIO(Olanow et al., 2008; 2009) studies.

In all these and additional clinical studies (eg Rabey et al., 2000; Thebault et al., 2004; Rascol, 
2005; Biglan et al., 2006; Siderowf and Stern, 2006) it could be shown that rasagiline is well tolerated, safe, improves motor symptoms, prevents motor complications in PD, has beneficial effects on quality of life parameters, is effective as monotherapy or in adjunctions to L-DOPA-therapy, is beneficial in early and late stages of PD, is safe when combined with all other PD-relevant therapies including COMT-inhibitors and may have diseasemodifying properties.

\section{Neuroprotection and disease-modification}

Selegiline and rasagiline are "suizide-inhibitors" which inhibit the enzyme irreversibly and for a rather long time. Therefore only newly synthesized enzyme will recover MAO activity sufficient to metabolize its substrates in an adequate amount. Positronemission tomography (PET) studies have shown a biological half-life time (HLT) of MAO-B recovery after selegiline - (Fowler et al., 1994) or rasagiline(Freedman et al., 2005) induced blockade of about $30 \sim 40$ days. As described earlier (Riederer and Lachenmayer, 2003; Gerlach et al., 2007) PETstudies are only in part suitable to detect the HLT of MAO-inhibitors as they only detect the distribution of radiolabeled inhibitor and its metabolites. In addition the exact kinetic properties underlying these PET-studies have been described only at random (Arnett et al., 1987). In contrast, measurement of PEA, the pure MAO-B substrate, in the urine of healthy individuals after selegiline dosing showed recovery (decline) of this amine concentration to normal values already $2 \sim 3$ days after withdrawal of selegiline (Clarke et al., 2001). Such data agree with other pharmacological studies as described by Riederer and Lachenmayer (2003) and point to the

Table 2. Nueroprotection in Parkinson's disease by selegline (prospective, randomized, double-blind, placebo-controlled studies)

\begin{tabular}{|c|c|c|c|}
\hline Autuors (year) & Name of the study & $\mathrm{N}$ & Result \\
\hline Tetrud and Langston (1989) & $\begin{array}{l}\text { Pilot study for } \\
\text { DATATOP }\end{array}$ & 44 & $\begin{array}{l}\text { Endpoint (levodopa) } \\
\text { Placebo } 312.1 \mathrm{~d} \\
\text { Selegiline } 548.9 \mathrm{~d}\end{array}$ \\
\hline $\begin{array}{l}\text { Parkinson Study Group } \\
\text { (1989a, b, 1993) }\end{array}$ & DATATOP & 800 & $\begin{array}{l}\text { Endpoint (levodopa) } \\
\text { After } 12 \text { months: } \\
\text { Placebo } 47 \% \\
\text { Selegiline } 26 \%\end{array}$ \\
\hline Myllylä et al. (1992) & Finnish trial & 47 & $\begin{array}{l}\text { Endpoint (levodopa) } \\
\text { Placebo } 372 \pm 28 \mathrm{~d} \\
\text { Selegiline } 545 \pm 94 \mathrm{~d}\end{array}$ \\
\hline Allain et al. (1993) & $\begin{array}{c}\text { French Selegiline } \\
\text { multicenter trial }\end{array}$ & 93 & $\begin{array}{l}\text { Endpoint (levodopa) } \\
\text { After } 3 \text { months: } \\
\text { Placebo } 18.4 \% \\
\text { Selegiline } 4.5 \%\end{array}$ \\
\hline Olanow et al. (1995) & SINDER & 101 & $\begin{array}{l}\text { Deterioration in UPDRS between baseline and final visit } \\
(14 \text { months }) \\
\text { Placebo }-5.8 \pm 1.4 \text { points } \\
\text { Selegiline }-0.4 \pm 1.3 \text { points }\end{array}$ \\
\hline przuntek et al. (1999) & SELEDO & 116 & $\begin{array}{l}\text { Primary end point: need for }>50 \% \text { increase in } \\
\text { levodopa dose } \\
\text { Placebo } 2.6 \text { years } \\
\text { Selegiline } 4.9 \text { years }\end{array}$ \\
\hline Larsen et al. $(1997,1999)$ & & 163 & $\begin{array}{l}\text { Patients treated with levodopa + selegiline developed } \\
\text { markedly less severe parkinsonism (not statistically } \\
\text { significant) and required lower doses of levodopa + placebo. }\end{array}$ \\
\hline Myllylä et al. (1992) & & 52 & $\begin{array}{l}\text { Endpoint (levodopa) after two years } \\
\text { Placebo } 545 \pm 90 \mathrm{~d} \\
\text { Selegiline } 372 \pm 28 \mathrm{~d}\end{array}$ \\
\hline Myllylä et al. (1997) & & 44 & $\begin{array}{l}\text { Levodopa dose ( } 5 \text { years): } \\
\text { Placebo } 725 \pm 78 \mathrm{mg} / \mathrm{d} \\
\text { Selegiline } 405 \pm 59 \mathrm{mg} / \mathrm{d}\end{array}$ \\
\hline
\end{tabular}

From Riederer and Lachenmayer 2003. 
Table 3. Datatop follow-up-clinical studies

\begin{tabular}{ll}
\hline N \\
\hline Parkinson Study Group (1996a) & $\cdot 310$ of originally 800 \\
& No levodopa necessary for the first $21 \pm 4$ month \\
& Patients remained blind regarding selegiline and tocopherol and received 10 mg selegiline per day \\
189 on selegiline, earlier need for levodopa & 121 without selegiline, later need for levodopa \\
& Result: loss of selegilines efficacy? \\
Patients of DATATOP with levodopa plus selegiline treatment for seven years were included \\
Patients that received placebo after three to five years treatment with selegiline were included \\
Results: improvement of ON-OFF fluctuations and motoricity in the selegiline's treated group \\
Less dyskinesias in the placebo group
\end{tabular}

conclusion that the HLT of MAO-B recovery after irreversible inhibition by selegiline is about 7 days. According to Green et al. (1977) an $80 \%$ inhibition of MAO-isoenzymes is necessary to increase concentration of biogenic amines significantly. This means that newly synthesized enzyme in the range of 20 to $30 \%$ is sufficient to lose any symptomatic behavioural effect after withdrawal of any MAOinhibitor. In line with this are studies by Youdim and Tipton (2002) who could not detect selegilineinduced stereotyped behaviour due to PEA increase 4 days after withdrawal of selegiline. At this time MAO-B recovery was already $20 \%$. Taking these findings into account a wash-out phase of two weeks or after selegiline/rasagiline withdrawal is sufficient to avoid any symptomatic effect of these MAO-l's. Therefore, the interpretations of the DATATOP-study and other follow-up trials to demonstrate a "neuroprotective" effect have to be reconsidered. If so, a neuroprotective effect of selegiline cannot be excluded (Riederer and Lachenmayer, 2003; Gerlach et al., 2007). Table 2 (taken in part from Riederer and Lachenmayer 2003 with permission) illustrates the major outcomes of the most important clinical long-term trials with selegiline. While treatment of patients in an early phase of PD with selegiline shows sufficient results regarding motoricity and disease-modification the unconclusive results of the DATATOP-follow-up clinical trials may demonstrate a bias in severity of patients grouping as given in the first follow-up study (Parkinson Study Group, 1996a) or that the patients have non-response based on diseaseprogression and/or accompanying diseases (Table 3). As there were no final conclusions about the neuroprotective effect of selegiline the development of more efficient clinical trial designs have been investigated including PET-controlled studies as shown with dopaminergic agonists. More recently the "delayed-start study design" has been developed as discussed by D'Agostino (2009). Rasagiline has been the first drug tested in such clinical trial. In fact the ADAGIO-study has given profound evidence for a disease-modifying effect of $1 \mathrm{mg} /$ day rasagiline, while there was not such benefit at a 2 $\mathrm{mg} /$ day dosis (Table 4). Although - and in comparison to the negative outcome of a delayedstart-study with pramipexol (Schapira et al., 2009) there is ample evidence for a significant diseasemodification with low dosis rasagiline this clinical outcome has been questioned recently (Ahlskog and Uitti, 2010; Sampaio and Ferreira, 2010; Schwarzschild, 2010). Caslake et al. (2009) conclude in their Cochrane Database report: "MAO-B inhibitors are one option for the early treatment of PD although they have weaker symptomatic effects than levodopa and dopamine agonists. They may reduce the rate of motor fluctuations compared with initial levodopa therapy and may have fewer significant adverse effects than the older agonists but data are too few to provide reliable conclusions".

Neuroprotective, neurorestaurative and diseasemodifying effects of selegiline and rasagiline are substantiated by in vitro-as well as in vivo experimental studies (Table 5). There is ample evidence that compounds attached to a propargylamino group induce molecular processes which act against cell death mechanisms like apoptosis, excitotoxicity and oxidative stress. These are non-MAO based mechanisms and they act not only on a functional level but rather on influencing gene expression and 
Table 4. Summary of rasagiline clinical studies

\begin{tabular}{|c|c|c|c|c|c|c|}
\hline Study & Design* & Duration & $\begin{array}{l}\text { Rasagiline } \\
\text { therapy }\end{array}$ & $\begin{array}{c}\text { No. } \\
\text { patients }\end{array}$ & $\begin{array}{l}\text { Primary } \\
\text { outcome }\end{array}$ & $\begin{array}{l}\text { Principle secondary } \\
\text { outcomes }\end{array}$ \\
\hline \multicolumn{7}{|c|}{ Monotherapy for early Parkinson's disease (Hoehn \&Yahr stage $\leq 3$ ) } \\
\hline $\begin{array}{l}\text { Stern et al. (2004) } \\
\text { (Phase II) }\end{array}$ & Placebo-controlled & 10 weeks & $\begin{array}{l}1,2 \text { or } \\
4 \mathrm{mg} / \text { day }\end{array}$ & 56 & $\begin{array}{l}\text { Safety and } \\
\text { tolerability }\end{array}$ & UPDRS, CGI \\
\hline $\begin{array}{l}\text { Parkinson Study Group } \\
\text { (2002) (TEMPO) } \\
\text { (Phase III) }\end{array}$ & Placebo-controlled & 6 months & $\begin{array}{l}1 \text { or } 2 \\
\mathrm{mg} / \text { day }\end{array}$ & 404 & $\begin{array}{l}\text { Efficacy } \\
\text { (UPDRS-Total) }\end{array}$ & $\begin{array}{l}\text { UPDRS subscales } \\
\text { (Mental, ADL, motor) }\end{array}$ \\
\hline $\begin{array}{l}\text { Parkinson Study Group } \\
\text { (2004) (TEMPO } \\
\text { delayed-start, } \\
\text { active-treatment phase) } \\
\text { (Phase III) }\end{array}$ & $\begin{array}{l}\text { Delayed-start (see } \\
\text { adove row for } \\
\text { initial } 6 \text { month } \\
\text { placebo-controlled } \\
\text { phase) }\end{array}$ & 12 months & $\begin{array}{l}1 \text { or } 2 \mathrm{mg} / \text { day } \\
\text { (12 months), or } \\
2 \mathrm{mg} / \text { day after } \\
6 \text { months placebo }\end{array}$ & 380 & $\begin{array}{l}\text { Efficacy } \\
\text { (UPDRS-Total) }\end{array}$ & $\begin{array}{l}\text { UPDRS subscales } \\
\text { (Mental, ADL, motor) }\end{array}$ \\
\hline \multicolumn{7}{|c|}{ Adjunct therapy for advanced Parkinson's disease (Hoehn \& Yahr stage $<5$ ) } \\
\hline $\begin{array}{l}\text { Rabey et al. (2000) } \\
\text { (Phase II) }\end{array}$ & Placebo-controlled & 12 weeks & $\begin{array}{l}0.5,1 \text { or } \\
2 \mathrm{mg} / \text { day }\end{array}$ & 70 & $\begin{array}{l}\text { Safety and } \\
\text { tolerability }\end{array}$ & $\begin{array}{l}\text { UPDRS, CGI, levodopa } \\
\text { dose }\end{array}$ \\
\hline $\begin{array}{l}\text { Parkinson Study Group } \\
\text { (2005) (PRESTO) } \\
\text { (Phase III) }\end{array}$ & Placebo-controlled & 6 months & $\begin{array}{c}0.5 \text { or } 1 \\
\mathrm{mg} / \text { day }\end{array}$ & 472 & $\begin{array}{l}\text { Efficacy (Total } \\
\text { daily OFF time) }\end{array}$ & $\begin{array}{l}\text { CGI, UPRDS-ADL OFF, } \\
\text { UPRDS-Motor ON, PD- } \\
\text { QUALIF }\end{array}$ \\
\hline $\begin{array}{l}\text { Rascol et al. (2005) } \\
\text { (LARGO) (Phase III) }\end{array}$ & $\begin{array}{l}\text { Placebo-controlled } \\
\text { plus an active } \\
\text { comparator } \\
\text { (entacapone } 200 \mathrm{mg} \\
\text { with each levodopa } \\
\text { dose) }\end{array}$ & 18 weeks & $1 \mathrm{mg} / \mathrm{day}$ & 687 & $\begin{array}{l}\text { Efficacy (total } \\
\text { daily OFF time) }\end{array}$ & $\begin{array}{l}\text { CGI, UPDRS-ADL OFF, } \\
\text { UPDRS-Motor On }\end{array}$ \\
\hline
\end{tabular}

${ }^{*}$ All studies were randomised, multi-centre, parallel-group and double-blind.

ADL: activities of daily living, CGI: clinical global impressions scale, LARGO: lasting effect in adjunct therapy with rasagiline given once daily, OFF: poor symptom response, ON: good symptom reponse, PD-QUALIF: parkinson's disease quality of life, PRESTO: Parkinson's rasagiline efficacy and safety in the treatment of OFF, TEMPO: trial of etanercept and methotrexate with radiographic patient outcomes, UPDRS-ADL: unified parkinson's disease rating scale-activities of daily living. From Rascol 2005.

Table 5A. Actions of propargylamine derived MAO-B-I

\begin{tabular}{ll}
\hline Antagonise & MPTP, MPP \\
& DSP4 \\
AF64 A & AHDA \\
& Excito toxins \\
Ischemia & \\
Antiapoptotic eg. Bcl-2 increase \\
Prevention of mPT in isolated mitochondria \\
Gene induction of Bcl-2, NFT's \\
APP processing inhibition \\
SEL RAS potentiate PEA behavioural response
\end{tabular}

As reviewed by Magyar et al 2010, Weinreb et al 2010, Naoi and Maruyama 2010.

protein synthesis. These more recent discoveries are in line with the earlier assumption of neuroprotective/ neurorestaurative/disease-modifying properties especially of this chemical class of compounds.

\section{Depression in PD}

With a prevalence of approximately $40 \%$ depression is considered to be the most frequent psychiatric
Table 5B. Non-MAO related actions of selegiline and rasagiline on molecular paramters in vitro

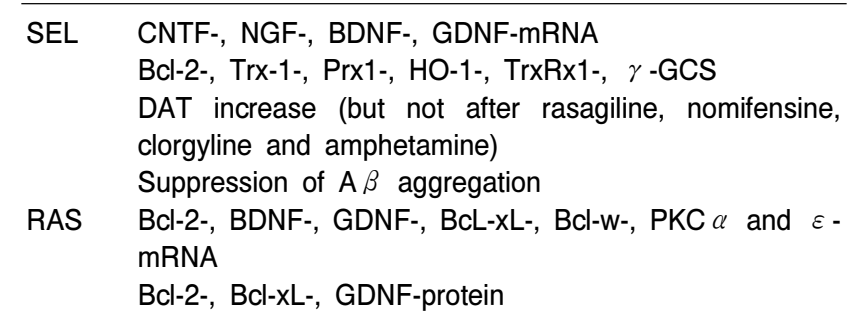

As reviewed by Magyar et al 2010, Weinreb et al 2010, Naoi and Maruyama 2010.

manifestation in PD (Burn, 2002; McDonald and DeLong, 2003; Veazey et al., 2005). Particular clinical features of the depressive symptom profile in patients with PD have been described (Wermuth and Bech, 2006; Brand et al., 2007) and recommendations towards better recognition given (Burn 2002). About $50 \%$ of the patients meet the criteria for major depressive disorder (MDD), 50\% have 
minor depression or dysthymia (Chaudhuri et al., 2006). Depression in PD is associated with increased disability and reduced quality of life, the impact of depressive symptoms in early PD especially should not be underestimated (Ravina et al., 2007).

\section{MAOls in depression}

While early studies suggested that MAOls were not as effective as other antidepressants, more recent studies have demonstrated that, when prescribed in adequate dosages, phenelzine and tranylcypromine are as effective as other antidepressants (Pare, 1985). Table 6 gives a summary

Table 5C. Non-MAO related actions of selegiline and rasagiline on molecular parameters in vivo

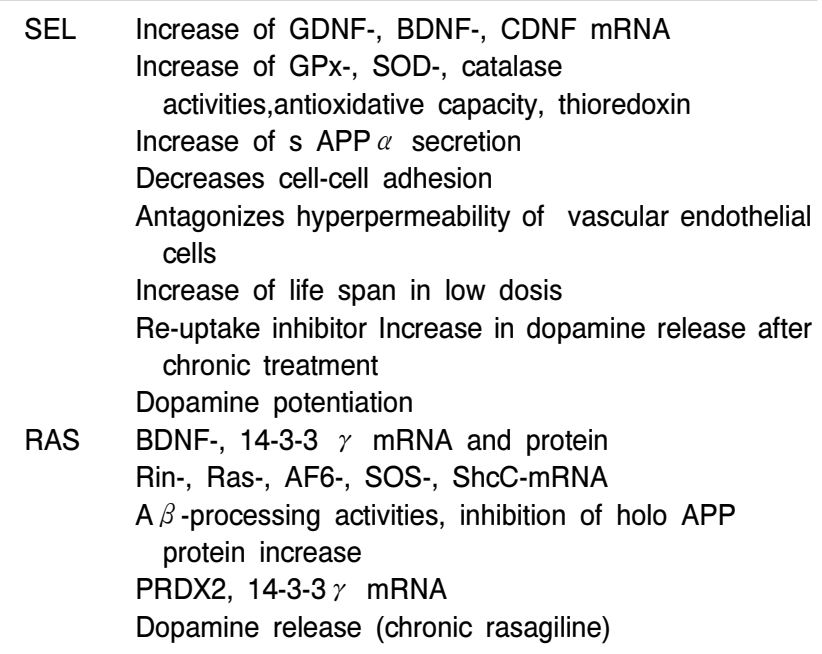

As reviewed by Magyar et al 2010, Weinreb et al 2010, Naoi and Maruyama 2010. of important controlled studies with tranylcypromine. In a recent study tranylcypromine, $60 \mathrm{mg}$ daily, was found effective in the treatment of panic disorder and social anxiety disorder comorbidity (Nardi et al., 2010).

The main indications for the classical irreversible MAOls are subgroups of depression such as atypical depression, dysthymia or for patients who do not respond to reuptake inhibitors, so-called therapy resistant depressions (Nolen et al., 1994; Paykel, 1995; Bauer et al., 2002).

The therapeutic efficacy of moclobemide has been assessed in numerous controlled studies comparing it with placebo and established antidepressants (for reviews see Laux, 1989; Fitton et al., 1992; Fulton and Benfield, 1996; Laux et al., 2002). An overview of the most relevant trials is given in Table 7.

Large trials in patients with major depression have generally confirmed that the efficacy of moclobemide is equivalent to that of TCAs beside some negative studies. Moclobemide treatment was usually fixed up to 300,400 or $600 \mathrm{mg} /$ day. It should be noted, however, that the use of dosages of up to $900 \mathrm{mg} / \mathrm{d}$ has been established due to clinical experience nowadays particularly in patients with refractory depression (Guentert et al., 1995). A meta-analysis of inpatient studies indicated that higher dosages ( $>450 \mathrm{mg} /$ day) of moclobemide are needed for full therapeutic effect in patients with severe depression (Angst et al., 1995).

Subgroup analyses of patients revealed moclo-

Table 6. Randomised, double-blind controlled studies with tranylcypromine (TCP) in the treatment of depressive disorders (from Laux et al., 2002)

\begin{tabular}{|c|c|c|c|c|}
\hline Study/Reference & $\mathrm{N}$ & $\begin{array}{c}\text { TCP-Dosage } \\
\text { (mg/day) }\end{array}$ & Duration (wk) & Results \\
\hline \multicolumn{5}{|l|}{ vs. Imipramin (I) } \\
\hline Freyhan (1960) & 147 & $30 \sim 150$ & $2 \sim 13$ & $\mathrm{TCP}>\mathrm{I}$ \\
\hline Spear et al. (1964) & 78 & 30 & 3 & $\mathrm{TCP}=\mathrm{I}$ \\
\hline Himmelhoch et al (1991) & 56 & 37 & 6 & $\mathrm{TCP}>\mathrm{I}$ \\
\hline Thase et al. (1992) & 16 & 39 & 6 & $\mathrm{TCP}>\mathrm{I}$ \\
\hline \multicolumn{5}{|l|}{ vs. Amitriptylin (A) } \\
\hline Razani et al. (1983) & 53 & 40 & 4 & $\mathrm{TCP}=\mathrm{A}$ \\
\hline \multicolumn{5}{|l|}{ vs. Nortriptylin (N) } \\
\hline White et al. (1984) & 183 & 44 & 4 & $\mathrm{TCP}=\mathrm{N}>\mathrm{PI}$ \\
\hline \multicolumn{5}{|l|}{ vs. Moclobemid (M) } \\
\hline Heinze et al. (1993) & 160 & $10 \sim 30$ & 4 & $\mathrm{TCP}>\mathrm{M}$ \\
\hline
\end{tabular}

Legend: =indicates equivalent to, >indicates more effective than references in this table are given in detail in Laux et al., 2002. 
Table 7. Randomised, double-blind controlled studies with moclobemide (M) in the treatment of depressive disorders (selection; references see Fulton and Benfield 1996; Laux et al., 2002)

\begin{tabular}{|c|c|c|c|c|c|c|}
\hline \multirow{2}{*}{ Study/Reference } & \multirow{2}{*}{$\mathrm{N}$} & \multirow{2}{*}{$\begin{array}{c}\text { M-Dosage } \\
\text { (mg/day) }\end{array}$} & \multirow{2}{*}{ Duration } & \multicolumn{2}{|c|}{ Response-rate (\%) } & \multirow{2}{*}{$\begin{array}{l}\text { Adverse } \\
\text { effects }\end{array}$} \\
\hline & & & & M & C & \\
\hline \multicolumn{7}{|l|}{ vs. Amitriptylin (A) } \\
\hline Bakish et al. (1992) & 82 & $200 \sim 600$ & 6 & 56 & 60 & $\mathrm{M}=\mathrm{PL}<\mathrm{A}$ \\
\hline Evans et al. (1992) & 48 & $300 \sim 400$ & 4 & 49 & 59 & $\mathrm{M}<\mathrm{A}$ \\
\hline \multicolumn{7}{|l|}{ vs. Clomipramin (C) } \\
\hline Dierick et al. (1990) & 53 & $300 \sim 600$ & 4 & 43 & 38 & $\mathrm{M}<\mathrm{C}$ \\
\hline Larsen et al. (1991) & 80 & $300 \sim 600$ & 6 & 46 & 72 & $\mathrm{M}<\mathrm{C}$ \\
\hline Guelfi et al. (1992) & 103 & $75 \sim 450$ & 6 & 66 & 72 & $\mathrm{M}<\mathrm{C}$ \\
\hline DUAG (1993) & 107 & 400 & 6 & 19 & 33 & $\mathrm{M}<\mathrm{C}$ \\
\hline Kragh-Sorensen et al. (1995) & 142 & 400 & 6 & 51 & 36 & $\mathrm{M}<\mathrm{C}$ \\
\hline Lecrubier et al. (1995) & 191 & $400 \sim 600$ & 12 & 63 & 65 & $\mathrm{M}<\mathrm{C}$ \\
\hline Jouvent et al. (1998) & 124 & 450 & 4 & $C>M$ & & $\mathrm{M}<\mathrm{C}$ \\
\hline \multicolumn{7}{|l|}{ vs. Doxepin (D) } \\
\hline Philipp et al. (1993) & 183 & 400 & 6 & 52 & 44 & $\mathrm{M}<\mathrm{D}$ \\
\hline \multicolumn{7}{|l|}{ vs. Imipramin (I) } \\
\hline Baumhackl et al. (1989) & 325 & $300 \sim 600$ & 4 & 58 & 58 & $\mathrm{M}<\mathrm{I}$ \\
\hline Versiani et al. (1989) & 273 & $300 \sim 600$ & 6 & 63 & 68 & $\mathrm{Pl}<\mathrm{M}<\mathrm{I}$ \\
\hline Lecrubier \& Guelfi (1990) & 291 & $300 \sim 600$ & 6 & $M=I$ & & $\mathrm{M}<\mathrm{I}$ \\
\hline Rimon et al. (1993) & 113 & $150 \sim 525$ & 4 & 71 & 64 & $M<1$ \\
\hline UK Study Group (1994) & 106 & $300 \sim 450$ & 6 & $M=I=P I$ & & $M<I$ \\
\hline \multicolumn{7}{|l|}{ vs. Maprotilin (M) } \\
\hline Gachoud et al. (1994) & 109 & $300 \sim 400$ & 4 & 55 & 59 & \\
\hline \multicolumn{7}{|l|}{ vs. Nortriptylin (N) } \\
\hline Nair et al. (1995) & 35 & $100 \sim 400$ & 7 & 23 & 33 & $\mathrm{M}=\mathrm{PI}<\mathrm{N}$ \\
\hline \multicolumn{7}{|l|}{ vs. Fluoxetin (F) } \\
\hline Williams et al. (1993) & 92 & $300 \sim 600$ & 6 & 72 & 59 & $M=F$ \\
\hline Lonnqvist et al. (1994) & 169 & $300 \sim 450$ & 6 & 67 & 57 & $M=F$ \\
\hline Reynaert et al. (1995) & 80 & $300 \sim 600$ & 6 & 47 & 48 & $M=F$ \\
\hline Lapierre et al. (1997) & 121 & $200 \sim 600$ & 6 & $M=F$ & & $M=F$ \\
\hline vs. Sertraline & 63 & $300 \sim 600$ & 13 & 73 & 42 & \\
\hline Turkcapar et al. (1998) & & & & 50 & $82^{*}$ & \\
\hline Sogaard et al. (1999) & 197 & $300 \sim 450$ & 12 & 68 & 78 & \\
\hline
\end{tabular}

C: comparator, =indicates equivalent to, $>$ indicates more effective/better tolerated than. *melancholic subtype.

bemide to be effective in patients with dysthymia or atypical depression especially (Lonnqvist et al., 1995).

Several trials have evaluated moclobemide alone or in combination with TCAs or SSRIs in the treatment of refractory depression (Bakish et al., 1995) reporting positive results. These data are limited and great caution is necessary because of the potential to induce the serotonin syndrome when combining moclobemide with serotoninergic drugs.

Uncontrolled long term follow-up studies demonstrated continued effectiveness of moclobemide over the treatment period of 1 year with more than $60 \%$ of patients having continued response (Fulton and Benfield, 1996). The role of MAOIs in mainte- nance treatment of depression still has to evaluated (Kennedy, 1997).

MAO-B inhibitors like selegiline in high dosage have been used in therapy-refractory depressions probably due to non-selective MAO effects (see review Laux, 1993). Recently, transdermal selegiline has been approved and released in the USA for treatment of major depression with a target dose of $6 \mathrm{mg} / 24$ hours. This dosage and application overcomes the MAO-B selectivity and leads to MAO-A inhibition, seen to be necessary for antidepressive effects. In several controlled studies selegiline transdermal system exhibited significant treatment effects on MDD including core depression symptoms, vegetative symptoms and motor retardation (Frampton and Plosker, 2007; Robinson et al., 2007). A combi- 
nation of selegiline and 5-hydroxytryptophan has been tested in a pilot study and proved antidepressant efficacy (Mendlewicz and Youdim, 1978).

\section{Treatment with antidepressants and MAOls in $P D$}

The scientific knowledge about the treatment with antidepressant drugs among PD patients is nearly missing. A pharmaco-epidemiological study in Danmark showed that persons treated with antiparkinson drugs have higher frequency of antidepressant drug treatment than have controls (Brandt-Christensen et al., 2007). Most authors conclude, that recommendations for the optimal drug treatment of depression in PD are difficult to give (Burn, 2002). Serotonin selective reuptake inhibitors (SSRIs) are given frequently, the benefit of SSRI treatment in PD has not been established, however (Wermuth and Bech, 2006).

Thirty-seven patients with early PD have been treated successfully with tranylcypromine (TCP), parkinsonian symptoms improved slightly, follow-up after 1.5 years on average revealed only slight worsening (Fahn and Chouinard, 1998). No other studies have been reported with TCP so far.

Ten patients with PD have been treated successfully with moclobemide vs. moclobemide with selegiline under tyramine restriction (Steuer and Ballering, 1997). Sufficient data allowing conclusions are missing.

\section{Dosage and administration}

The recommended initial dosage of tranylcypromine is $10 \sim 20 \mathrm{mg} /$ day, of moclobemide 300 to 450 $\mathrm{mg} /$ day, given in 2 to 3 divided doses. Subsequent dosage increase to a maximum of $60 \mathrm{mg} / \mathrm{day}, 900$ $\mathrm{mg} /$ day respectively, are made as clinically indicated (Beckmann and Laux, 1991; Fitton et al., 1992). Clinical experience and studies in the last years clearly have shown the necessity of higher dosage of moclobemide pointing out the lack of early sufficient dose-finding studies. Recommended daily doses of phenelzine are 30 to $90 \mathrm{mg}$, of isocarboxazid 30 to $60 \mathrm{mg}$, respectively.

Dietary restrictions are essential for tranylcypromine (tyramine-rich food), unnecessary for moclobemide taken at the end of a meal. A 2 week wash-out period is required for switching between tranylcy- promine and other classes of antidepressants, not between moclobemide and other antidepressants.

In patients with severe hepatic impairment, tranylcypromine and moclobemide dosages should be reduced by one-third to one-half in such patients (Atkinson and Ditman, 1965; Fitton et al., 1992).

The target dose of selegiline transdermal (not released in Europe so far) is $6 \mathrm{mg} / 24$ hours.

\section{Tolerability and safety}

The most frequent adverse effects of irreversible MAOIs are orthostatic hypotension, sleep disturbances and nervousness/agitation (Remick et al., 1989). The mostly limiting factor in the use of these MAOls is the potential for dangerous interactions with tyramine-rich foods and sympathomimetic and serotoninergic substances. Therefore, prescription is only possible to patients being strongly compliant with dietary restrictions. In the case of RIMAs like moclobemide there is no need for dietary restrictions. For "selegiline transdermal system" tyramine dietary restrictions are not needed. The incidence of the most frequently reported adverse effects from patients receiving MAOls are summarised in Table 7.

Insomnia and impotency in men have been the most frequent side effects of TCP in patients with early PD (Fahn and Chouinard, 1998).

Unlike nonselective, irreversible MAOls and tricyclics, moclobemide has little effect on the cardiovascular system and lacks anticholinergic properties associated with TCAs (Moll et al., 1994; Fulton and Benfield, 1996). In almost all controlled clinical studies comparing moclobemide with TCAs moclobemide showed clearly superior tolerability (Versiani et al., 1990; Fitton et al., 1992; Fulton and Benfield, 1996). Headache, insomnia and agitation were the only one side effects being reported more frequently with moclobemide compared to re-uptake inhibiting antidepressants. Dizziness and nausea have been noticed additionally. No systematic changes in blood pressure were observed with moclobemide, whereas increases in both blood pressure and pulse were recorded for tranylcypromine (Laux et al., 1996). Body weight gain has been observed with phenelzine and isocarboxazid, no clearcut cases with tranylcypromine or moclobemide have been reported (Cantu and Korek, 1988). Compared to SSRIs 
moclobemide showed fewer gastrointestinal adverse effects and sexual dysfunction have not been reported with moclobemide (Philipp et al., 1999).

Regarding cognitive functions data in favour of moclobemide compared to other antidepressants are available: Behavioural toxicity assessed by choice reaction time is very low or missing, psychomotor functions seem not be influenced negatively perhaps even improved (Hindmarch et al., 1992).

The principal side effects of selegiline transdermal were local dermal reactions and (dose-related) insomnia (Robinson and Amsterdam, 2008).

After ingestion of up to $20 \mathrm{~g}$ of moclobemide no fatalities were observed, so moclobemide can be considered as a 'safe' antidepressant (DeJonghe and Swinkels, 1992; Chen and Ruch, 1993). Several fatal overdoses have been reported when moclobemide was combined with serotoninergic antidepressants like citalopram, clomipramine or fluoxetine due to occurrence of a serotonin syndrome (Neuvonen et al., 1993). In contrast, irreversible MAOls like tranylcypromine must be regarded as less safe regarding to the fatal toxicity index (Henry et al., 1995).

\section{Side effects of selegiline and rasagiline}

Selegiline is well tolerated. Side effects/adverse reactions like sleeplessness, nausea, vomiting, dizziness, dry mouth, orthostatic hypotension and dyskinesias have been all observed in the range of 2 $5 \%$ of PD patients (Parkinson-Study-Group, 1993; Reichmann et al., 2002) which is comparable to placebo. Other side effects like headache, heart beating, dyspnoe, edema, confusion, micturition dysfunction, loss of appetite and anxiety are even more rare and below 2\% (Reichmann et al., 2002).

\section{Rasagiline}

Adverse reactions as seen with other dopaminergic drugs, like nausea, vomiting, orthostatic hypotension, somnolence, hallucinations and dyskinesias are tolerable in most cases. Vomiting was noteable at $1 \mathrm{mg} /$ day in the PRESTO-study, as was the occurrence of dyskinesias but such adverse reactions have not been described in other clinical trials like the LARGO-trial. Cognitive and behavioural symptoms of PD are not changed/worsened at 1 $\mathrm{mg} /$ day rasagiline (Elmer et al., 2006).
Although interactions may be suggested when MAO-B inhibitors are combined with COMT-inhibitors, such adverse reactions have not been reported to be of relevance. In fact rasagiline is effective and well tolerated in PD patients with L-DOPA induced motor fluctuations receiving entacapone (Elmer et al., 2006).

\section{The cardiovascular risk in selegiline and rasagiline treated $P D$}

Selegiline is metabolized mainly to desmethylselegiline, L-amphetamine and L-metamphetamine. Given these facts there was always a profound discussion about the contribution of these metabolites to selegiline's clinical symptomatic effects (Reynolds et al., 1978; Elsworth et al., 1982) and selegilines adverse reactions, predominantly of cardiovascular origin (Churchyard et al., 1997). LAmphetamine has about a ten times lower activity on the peripheral sympathetic system compared to D-amphetamine. On the other hand, both are equipotent in blocking striatal dopamine uptake (Coyle and Snyder, 1969). A clinical trial of daily 10 $\mathrm{mg}$ selegiline vs. the calculated dosis and ratio of L-amphetamine and L- metamphetamine in PD patients came to the conclusion that selegiline did show antiakinetic efficacy while the metabolites did not (Elsworth et al., 1982). Therefore, selegiline is not acting via the amphetamine metabolites. Also, from the side effect profile as reported in the large selegiline based trials there is no evidence for enhanced cardiovascular risk (eg. Parkinson Study Group, 1989; 1993). This holds true also when selegiline is compared to treatment based on L-DOPA and dopaminergic receptor agonists. However, head-to head comparison is missing.

Nevertheless, to avoid further such discussion a sublingual galenic form of selegiline treatment has been developed named Zydis-selegiline (Clarke et al., 2003a; 2003b). This "melting-tablet" avoids a firstpass effect and therefore a significant break-down to L-amphetamine and L-metamphetamine in the range of $90 \%$. A reduction of the daily dosis of 10 $\mathrm{mg}$ selegiline to $1,25 \mathrm{mg}$ selegiline is advised. The bioavailability of selegiline when given as "meltingtablet" is more homogene and better reproduceable compared to the peroral type of application (Clarke et al., 2003a; 2003b). In addition a transdermal 
galenic form of selegiline has been developed for the treatment of major depression again reducing selegilines first-pass biotransformation (Frampton and Plosker, 2007; Robinson et al., 2007).

Melting tablet and transdermal selegiline avoid first-pass metabolism, cause higher drug availability in MAO-B preferring organs and reduce the concentration of metabolites. Increased drug concentration may cause significant inhibition of both MAO-B and $-A$ in brain but not in the periphery. This explains selegilines antidepressant activity when combined with 5-hydroxytryptophan without the cheese-effect and without the serotonin syndrome (Mendlewicz and Youdim, 1978).

Under clinical conditions selegiline is not more "toxic" than other dopaminergic treatment strategies. In fact the side effect and adverse reaction profile of selegiline has been evaluated as being well tolerated and "mild" compared to other PD treatment strategies, eg. orthostatic reactions have been noteable in only $3,7 \%$ of patients (Reichmann et al., 2002).

It should be mentioned that L-amphetamine is in clinical use for the treatment of attention-deficithyperactivity syndrome (ADHD) without major side effects. In line with this are several studies as summarized by Reidenberg (1994) showing no abuse liability of selegiline.

The contribution of desmethylselegiline (DMS) to the effects of selegiline has been underestimated so far. DMS is a weak inhibitor of MAO-B and seems to have glutathione related properties (Heinonen, 1997; Heinonen et al., 1997).

In contrast to selegiline, rasagiline is not metabolized to amphetamine. The main metabolite of rasagiline is aminoindan. Therefore any cardiovascular responses of rasagiline are neglectible as shown in animal studies (Finberg et al., 2006) and in all clinical trials including the TEMPO- (Parkinson Study Group, 2002), PRESTO- (Parkinson Study Group, 2005), LARGO- (Rascol et al., 2005) and ADAGIO-study (Olanow et al., 2008; 2009).

In the recommended therapeutic dosis of $1 \mathrm{mg} /$ day rasagiline does not potentiate the tyramine induced cheese-effect (de Marcaida et al., 2006). This is in agreement with earlier findings in rats and cats (Finberg et al., 1981; Chen and Swope, 2005; Finberg et al., 2006).

\section{Drug interactions}

Coadministration of SSRIs and other serotoninergic substances to tranylcypromine is contraindicated due to the risk of serotonin syndrome. With moclobemide great caution should be exercised with this combination. Severe, sometimes fatal, interactions between nonselective, irreversible MAOls, moclobemide as well as selegiline and pethidine and dextromethorphan have been reported. Indirectly acting sympathomimetics (tyramine, ephedrine, pseudoephedrine) should be administered with caution in patients treated with MAOIs (Dingemanse, 1993).

The elimination of moclobemide is significantly reduced by cimetidine making dose adjustment necessary.

Although selegiline has been reported to have antidepressant actions when combined with 5-hydroxytryptophan (Mendlewicz and Youdim, 1978) MAO-Binhibitors may not be safe enough to avoid the "serotonin-syndrome" when given in adjunct to serotonin-reuptake inhibitors (SSRIs) to treat depression and anxiety in PD patients. However, there is a low risk $(0,24 \%)$ to develop the "serotoninsyndrome" in selegiline treated patients (Richard et al., 1997). Also the results of a small number of PD patients treated with tricyclics and SSRIs plus rasagiline in the TEMPO-, PRESTO- and LARGOstudies do not give evidence for the "serotoninsyndrome", the population incidence of serotonin toxicity in those patients has a $9,5 \%$ probability of being less than 1, 2\% (Pannisset et al., 2007; Montgomery and Panisset, 2009). However, a clinical trial with a biostatistic power relevant to give a definite answer to the problem is missing. Therefore MAO-B inhibitors have not to be combined with drugs stimulating the serotoninergic system.

Meperidin plus selegiline has been reported to be dangerous as it causes severe hypertension (Zornberg et al., 1991).

Selegiline transdermal without tyramine restriction revealed no acute hypertensive reactions in trials, until more data are available, foods that are rich sources of tyramine should be avoided, however.

As described by Chen and Swope (2005) CYP1A2 inhibitors (cimetidine, fluvoxamine, ciprofloxacin) increase the area under curve of rasagiline, 
while CYP1A2 inducers like omeprazol decrease it, as it may decrease in heavy smokers.

Minor time-dependent mechanism-based inhibition of CYP2D6 has been described for selegiline and moclobemid in experimental designs; the significance in human beings remains to be investigated (Polasek et al., 2006). For selegiline interactions with CYP $3 \mathrm{~A} 4$ and CYP 2E1 may be relevant too.

\section{Expert commentary}

While selective MAO-B-inhibitors demonstrate a significant benefit in PD and improve motoricity and motor fluctuations eventually causing disease-modification in general MAOls to date play a subordinate therapeutic role in the treatment of depression in PD compared to SSRIs or reboxetine, a selective noradrenergic reuptake inhibitor. This attitude is primarily due to the risk of adverse effects and compliance problems (e.g. dietary restrictions, interaction problems) with MAOls. Moclobemide according to its favourable adverse effect, interaction and toxicity profile can be used in depressed Parkinson patients when activating properties are necessary, especially.

Overall, the clinical use of MAOIs may be limited by the possible adverse effects of restlessness and insomnia - but see rasagiline. As far as long term and prophylactic treatments are concerned, the place of MAOls still has to be verified as antidepressant or antidementive drugs in PD (Tariot et al., 1987; Sano et al., 1997; Filip and Kolibas, 1999; Sterling et al., 2002; Elmer et al., 2006; Carageorgiou et al., 2008). Controlled studies are urgent needed for final evaluation and recommendations.

\section{Five-year view}

It would be worthwile to perform clinical studies to demonstrate the capacity of MAO-B inhibitors as antidepressants and antidementive drugs. New substances like ladostigil (MAOA/B inhibitor; AchEinhibitor) or $\mathrm{M} 30$ and HLA-20 (MAO-A/B inhibitor, iron-chelator) and M30P (MAO-A/B inhibitor, carbonate cholinesterase inhibitor) give future aspects of using MAO-l's in a variety of clinical indications (Weinreb et al., 2010). The pharmacological properties of aminoindan have to be elucidated as they may be neuroprotective (Bar-Am et al., 2010).

\section{Key issues}

Head-to-head clinical trials are necessary to demonstrate disease-modification using improved delayed-start-study designs with selegiline and rasagiline. Otherwise no objective comparison can be made between the neuroprotective/neurorestaurative properties of selegiline and rasagiline.

Aminoindan has to be tested in vivo in order to get insight into its anti-parkinsonian efficacy.

The many molecular biological and -genetic data evolved from in-vitro studies have to be confirmed in in-vivo experiments to prove relevance in human beings. That other MAO-Is, even reversible ones might well be important in neuroprotection/disease modification is a just ongoing important issue. In addition, the respective role of MAO-A has to be elucidated in more detail.

\section{REFERENCES}

Ahlskog JE and Uitti RJ (2010) Rasagiline, Parkinson neuroprotection and delayed-start trials. Neurology 74:1143-1148.

Angst J, Amrein R and Stabl M (1995) Moclobemide and tricyclic antidepressants in severe depression: meta-analysis and prospective studies. J Clin Psychopharmacol 15:16-23.

Arnett CD, Fowler JS, MacGregor RR, Schlyer DJ, Wolf AP, Långström B and Halldin C (1987) Turnover of brain monoamine oxidase measured in vivo by positron emission tomography using L-[11C]deprenyl. J Neurochem 49:522-527.

Atkinson R and Ditman K (1965) Tranylcypromine: a review. Clin Pharmacol Ther 6:631-655.

Bakish D, Hooper C and West D (1995) Moclobemide and specific serotonin re-uptkae inhibitor combination treatment of resistant anxiety and depressive disorders. Hum Psychopharmacol 10:105-109.

Ban TA, Healy D and Shorter E (2004) Reflections on twentiethcentury psychopharmacology. Vol 4. Animula, Publishing House, Budapest, Hungary.

Bar-Am O, Weinreb O, Amit T and Yoduim MBH (2005) Regulation of $\mathrm{Bcl}-2$ protein familiy proteins, neurotrophic fators, and APP processing in the neurorescue activity of progargylamine. FASEB $J$ 19:1899-1901.

Bar-Am O, Weinreb O, Amit T and Youdim MBH (2010) The neuroprotective mechanism of 1-(R)-aminoindan, the major metabolite of the anti-parkinsonian drug rasagiline. J Neurochem 112:1131-1137.

Bauer M, Whybrow $P$, Angst $J$, Versiani $M$, Möller HJ and WFSBP Task Force (2002) World Federation of Societies of Biological Psychiatry (WFSBP) Guidelines for biological treatment of unipolar depressive disorders, part 1: Acute and continuation treatment of major depressive disorders. World J Biol Psychiatry 3:5-43.

Beckmann H and Laux G (1991) Aktuelles zur Therapie mit MAO-Hemmern. Krankenhauspsychiatrie 2:201-202.

Berlin I, Saïd S, Spreux-Varoquaux O, Launay JM, Olivares 
R, Millet V, Lecrubier $Y$ and Puech AJ (1995) A reversible monoamine oxidase $A$ inhibitor (moclobemide) facilitates smoking cessation and abstinence in heavy, dependent smokers. Clin Pharmacol Ther 58:444-452.

Bernheimer H, Birkmayer W and Hornykiewicz O (1962) Verhalten der monoaminoxydase im gehirn des menschen nach therapie mit monoaminoxydase-hemmern. Wr Klin Wschr 74:558-559.

Bernheimer H, Birkmayer W and Hornykiewicz O (1963) Zur Biochemie des Parkinson-Syndromes des Menschen. Einflu $\beta$ der Monoaminoxydase-Hemmer-Therapie auf die Konzentration des Dopamins, Noradrenalins und 5-Hydroxytryptamins im Gehirn. Klin Wschr 41:465.

Bernheimer H, Birkmayer W and Hornykiewicz O (1961) Verteilung des 5-Hydroxytryptamins (Serotonin) im gehirn des menschen und sein verhalten bei patienten mit parkinson-syndrom. Klin Wschr 39:1056-1059.

Biglan KM, Schwid S, Eberly S, Blindauer K, Fahn S, Goren T, Kieburtz K, Oakes D, Plumb S, Siderowf A, Stern M and Shoulson I; Parkinson Study Group (2006) Rasagiline improves quality of life in patients with early Parkinson's disease. Mov Dis 21:616-623.

Birkmayer W and Hornykiewicz O (1962) Der L-Dioxyphenylalanin (=L-DOPA). Effekte beim Parkinson-Syndrom des Menschen: Zur Pathogenese und Behandlung der ParkinsonAkinese Arch Psychiatr Nervenkr Z Gesamte Neurol Psychiatr 203:560-574.

Birkmayer W and Hornykiewicz O (1964) Weitere experimentelle Untersuchungen über L-DOPA beim Parkinson-Syndrom und Reserpin-Parkinsonismus. Arch Psychiat $u$ Zschr fd ges Neurol 206:367.

Birkmayer W and Hornykiewicz O (1961) Der L-3,4-Dioxyphenylalanin (=DOPA)-Effekt bei der Parkinson-Akinese. Wr klin Wschr 73:787-788.

Birkmayer W, Knoll J, Riederer P and Youdim MB (1983) (-)-Deprenyl leads to prolongation of L-dopa efficacy in Parkinson's disease. Mod Probl Pharmacopsychiatry 19:170176.

Birkmayer W, Knoll J, Riederer P, Youdim MB, Hars V and Marton J (1985) Increased life expectancy resulting from addition of L-deprenyl to Madopar ${ }^{\mathrm{R}}$ treatment in Parkinson's disease: a longterm study. J Neural Transm 64:113-127.

Birkmayer W, Riederer P, Abrozi L and Youdim MBH (1977) Implications of combined treatment with "Madopar" and Ldeprenil in Parkinson's disease. A long-term study. Lancet 1:439-443.

Birkmayer W, Riederer P, Youdim MBH and Linauer W (1975) The potentiation of the anti akinetic effect after L-dopa treatment by an inhibitor of MAO-B, Deprenil. J Neural Transm 36:303-326.

Brand S, Dodel R, Hautzinger M, Günder G, Althaus A and Schneider F (2007) Depression in Parkinson's disease. Assessment and treatment. Nervenarzt 78:715-728.

Brandt-Christensen M, Kvist K, Nilsson FM, Andersen PK and Kessing LV (2007) Treatment with antiparkinson and antidepressant drugs: a register-based, pharmaco-epidemiological study. Mov Disord 22:2037-2042.

Burn DJ (2002) Beyond the iron mask: towards better recognition and treatment of depression associated with Parkinson's disease. Mov Disord 17:445-454.

Cantu T and Korek J (1988) Monoamine oxidase inhibitors and weight gain. Drug Intell Clin Pharm 22:755-759.

Carageorgiou $\mathrm{H}$, Sideris AC, Mesari I, Liakou $\mathrm{Cl}$ and Tskiris $S$ (2008) The effects of rivastigmine plus selegiline on brain acetylcholinesterase, $\left(\mathrm{Na}^{+} \mathrm{K}^{+}\right)-, \mathrm{Mg}^{2+}$-ATPase activities, antioxidant status, and learining performance of aged rats. Neuropsychiatr Dis Treat 4:687-699.

Caslake R, Macleod A, Ives $\mathrm{N}$, Stowe $\mathrm{R}$ and Counsell $\mathrm{C}$ (2009) Monoamine oxidase $B$ inhibitors versus other dopaminergic agents in early Parkinson's disease. Cochrane Database Syst Rev (4):CD006661.

Chan-Palay V (1992) Depression and senile dementia of the Alzheimer type: a role for moclobemide. Psychopharmacology (Berl) 106:S137-S139.

Chaudhuri KR, Healy DG and Schapira AH (2006) Non-motor symptoms of Parkinson's disease: diagnosis and management. Lancet Neurol 5:235-245.

Chen DT and Ruch R (1993) Safety of moclobemide in clinical use. Clin Neuropharmacol 16:S63-68.

Chen JJ and Swope DM (2005) Clinical Pharmacology of Rasagiline: A Novel, Second-Generation Propargylamine for the Treatment of Parkinson Disease. J Clin Pharmacol 45:878-894.

Churchyard A, Mathias CJ, Boonkongchuen $P$ and Lees AJ (1997) Autonomic effects of selegiline: possible cardiovascular toxicity in Parkinson's disease. J Neurol Neurosurg Psychiatry 63:228-234

Clarke A (2001) Xilopar - The evolution of selegiline. Satellitensymposium "Neuroprotection beim Parkinson-Syndrom Back to the future?". Kongress der Deutschen Gesellschaft für Neurologie, 22. September, Aachen (Nervenheilkunde 10/2001).

Clarke A, Brewer F, Johnson ES, Mallard N, Hartig F, Taylor S and Corn TH (2003a) A new formulation of selegiline: improved bioavailability and selectivity of MAO-B inhibition. J Neural Transm 110:1241-1255.

Clarke A, Johnson ES, Mallard N, Corn TH, Johnston A, Boyce M, Warrington S and MacMahon DG (2003b) A new lowdose formulation of selegiline: clinical efficacy, patient preferene and selectivity for MAO-B inhibition. I Neural Transm 110:1257-1271.

Coyle JT and Snyder SH (1969) Antiparkinsonian drugs: inhibition of dopamine uptake in the corpus striatum as a possible mechanism of action. Science 166:899.

D'Agostino RB (2009) The delayed-start study design. N Engl J Med 361:1304-1306.

Degkwitz R, Frowein R, Kulenkampff C and Mohs U (1960) über die Wirkungen des L-DOPA beim Menschen und deren Beeinflussung durch Reserpin, Iproniazid und Vitamin B6. Klin Wschr 38:120.

DeJonghe $F$ and Swinkels J (1992) The safety of antidepressants. Drugs 41:40-47.

DeMarcaida JA, Schwid SR, White WB, Blindauer K, Fahn S, Kieburtz K, Stern M and Shoulson I; Parkinson Study Group TEMPO; PRESTO Tyramine Sub study Investigators and Coordinators (2006) Effects of tyramine administration in parkinson's disease patients treated with selective mao-b inhibitor rasagiline. Mov Disord 21:1716-1721.

Dingemanse J (1993) An update of recent moclobemide interaction data. Int Clin Psychopharmacol 7:167-180.

Elmer L, Schwid S, Eberly S, Goetz C, Fahn S, Kieburtz K Oakes D, Blindauer K, Salzman P, Oren S, Prisco UL, Stern 
M and Shoulson I; Parkinson Study Group TEMPO; PRESTO Investigators (2006) Rasagiline-associated motor improvement in PD occurs without worsening of cognitive and behavioral symptoms. J Neurol Sci 248:78-83.

Elsworth JD, Glover V, Reynolds GP, Sandler M, Lees AJ, Phuapradit P, Shaw KM, Stern GM and Kumar P (1978) Deprenyl administration in man: a selective monoamine oxidase B inhibitor without the "cheese effect". Psychopharmacology (Berl) 57:33-38.

Elsworth JD, Sandler M, Lees AJ, Ward C and Stern GM (1982) The contributuion of amphetamine metabolites of (-)-deprenyls to its antiparkinsonian properties. I Neural Transm 54: 105-110.

Fahn S and Chouinard S (1998) Experience with tranylcypromine in early Parkinson's disease. J Neural Transm Suppl 52:49-61.

Filip V and Kolibas E (1999) Selegiline in the treatment of Alzheimer's disease: a long-term randomized placebo-controlled trial. Czech and Slovak senile dementia of Alzheimer type study group. J Psychiatry Neurosci 24:234-243.

Finberg JP, Gross A, Bar-Am O, Friedman R, Loboda $Y$ and Youdim MB (2006) Cardiovascular responses to combined treatment with selective monoamine oxidase type $B$ inhibitors and L-DOPA in the rat. $\mathrm{Br} J$ Pharmacol 149:647656.

Finberg JP, Takeshima T, Johnston JM and Commissiong JW (1998) Increased survival of dopaminergic neurons by rasagiline, a monoamine oxidase B inhibitor. Neuroreport 9:703-707.

Finberg JP, Tenne M and Youdim MBH (1981) Tyramine antagonistic properties of AGN 1135, an irreversible inhibitor of monoamine oxidase type $\mathrm{B} . \mathrm{Br} J$ Pharmacol 73:65-74

Fitton A, Faulds D and Goa K (1992) Moclobemide: a review of its pharmacological properties and therapeutic use in depressive illness. Drugs 43:561-596.

Foley P (2001) Beans, roots and leaves. A history of the chemical therapy of parkinsonism.

Foley P, Mizuno Y, Nagatsu T, Sano A, Youdim MBH, McGeer P, McGeer E and Riederer P (2000) The L-DOPA story an early Japanese contribution. Elsevier: Parkinsonism and Related Disorders. Mov Dis 6:1.

Fowler JS, Volkow ND, Logan J, Wang GJ, MacGregor RR, Schyler D, Wolf AP, Pappas N, Alexoff D Shea C et al (1994) Slow recovery of human brain MAO B after L-deprenyl (Selegeline) withdrawal. Synapse 18:86-93.

Frampton JE and Plosker GL (2007) Selegiline transdermal system: in the treatment of major depressive disorder. Drugs 67:257-265.

Freedman M, Rewilak D, Terri T, Cohen S, Gordon AS, Shandling M and Logan AG (1998) L-deprenyl in Alzheimer's disease: cognitive and behavioral effects. Neurology 50: 660-668.

Freedman NM, Mishani E, Krausz Y, Weininger J, Lester H, Blaugrund E, Ehrlich D and Chisin R (2005) In Vivo Measurement of Brain Monoamine Oxidase B Occupancy by Rasagiline, Using 11C-L-Deprenyl and PET. J Nucl Med 46:1618-1624.

Fulton B, Benfield P and Moclobemide K (1996) An update of its pharmacological properties and therapeutic use. Drugs 52:450-474
Gerlach M, Reichmann H and Riederer P (2007) Die ParkinsonKrankheit. Grundlagen, Klinik, Therapie. 4. Auflage. Springer Wien, New York

Glover V, Sandler M, Owen F et al. (1977) Dopamine is a monoamine oxidase B substrate in men. Nature 80-81.

Götz ME, Breithaupt W, Wautter J, Kupsch A, Scharz J, Oertel WH, Youdim MBH, Riederer $P$ and Gerlach $M$ (1998) Chronic TVP-1012 (rasagiline) dose-activity response of monoamine oxidases $A$ and $B$ in the brain of the common marmoset. J Neural Transm Suppl 52:271-278.

Green AR, Mitchell BD, Tordoff AF and Youdim MBH (1977) Evidence for dopamine deamination by both type $A$ and type $B$ monoamine oxidase in rat brain in vivo and for the degree of inhibition of enzyme necessary for increased functional activity of dopamine and 5-hydroytryptamine. $\mathrm{Br}$ $J$ Pharmacol 60:343-349.

Guentert TW, Banken L, Hilton S and Holford NH (1995) Moclobemide: relationships between dose, drug concentration in plasma, and occurrence of adverse events. J Clin Psychopharmacol 15:84S-94S.

Heikkila RE, Duvoisin RC, Finberg JPM and Youdim MBH (1985) Prevention of MPTP-induced neurotoxicity by AGN1133 and $A G N-1135$, selective inhibitors of monoamine oxidase-B. Eur J Pharmacol 116:313-317.

Heinonen E (1997) Long-term efficacy and safety of selegiline in the treatment of Parkinson's disease review. 12th Int. Symposium on Parkinson's Disease, 23.-26. March, London.

Heinonen EH, Anttila MI, Karnani HL, Nyman LM, Vuorinen JA, Pyykkö KA and Lammintausta RA (1997) DesmethyIselegiline, a metabolite of selegiline, is an irreversible inhibitor of monoamine oxidase type $B$ in humans. J Clin Pharmacol 37:602-609.

Heinonen EH, Anttila MI and Lammintausta RAS. (1993) Pharmacokinetics and Clinical Pharmacology of Selegiline. In: Inhibitors of monoamine oxidase B. Pharmacology and Clinical Use in Neurodegenerative Disorders (Szelanyi I, ed), pp 201-213. Birkhäuser Verlag, Basel/Switzerland.

Heinonen EH and Myllylä V (1998) Safety of selegiline (deprenyl) in the treatment of Parkinson's disease. Drug Saf 19:11-22.

Henry JA, Alexander C and Sener E (1995) Relative mortality from overdose of antidepressants. BMJ 310:221-224.

Hindmarch I, Alford C, Barwell F (1992) Measuring the sideeffects of psychotropics: the behavioural toxicity of antidepressants. J Psychopharmacol 6:198-203.

Johnston JP (1968) Some observations upon a new inhibitor of monoamine oxidase in brain tissue. Biochem Pharmacol 17:1285-1297.

Kennedy SH (1997) Continuation and maintenance treatments in major depression: the neglected role of monoamine oxidase inhibitors. J Psychiatry Neurosci 22:127-131.

Kline NS (1958) Clinical experience with iproniazid (marsilid) $J$ Clin Exp Psychopathol 19:72-78.

Knoll J (1988) The striatal dopamine dependency of life span in male rats: longevity study with (-)-deprenyl. Mech Ageing Dev 46:237-262.

Knoll J, Ecseri Z, Kelemen K, Nievel J and Knoll B (1965) Phenylisopropylmenthylpropinylamine (E250), a new spectrum psychic energizer. Arch Int Pharmacodyn Ther 155:154-164.

Knoll J and Magyar K (1972) Some puzzling pharmacological effects of monoamine oxidase inhibitors. Adv Biochem 
Psychopahrmacol 5:393-408.

Kornhuber J, Konradi C, Mack-Burkhardt F, Riederer P, Heinsen $\mathrm{H}$ and Beckmann $\mathrm{H}$ (1989) Ontogenesis of monoamine oxidase- $A$ and $-B$ in the human brain frontal cortex. Brain Res 499:81-86.

Kupsch A, Sautter J, Gotz M, Breithaput W, Schwarz J, Youdim MBH, Riederer $\mathrm{P}$, Gerlach $\mathrm{M}$ and Oertel $\mathrm{WH}$ (2001) Monoamine oxidase-inhibition and MPTP-induced neurotoxicity in the non -human primate: comparison of rasagline (TVP 1012) with selegiline. J Neural Transm 108:985-1009.

Lamensdorf I, Porat S, Simantov R and Finberg JP (1999) Effect of low-dose treatment with selegiline on dopamine transporter (DAT) expression and amphetamine-induced dopamine release in vivo. $\mathrm{Br} J$ Pharmacol 126:997-1002.

Laux G (1993) Do MAO-B inhibitors have any role in the treatment of depression? In: Inhibitors of monoamine oxidase B. (Szelenyi I, ed), pp 319-326. Birkhäuser, Basel.

Laux G (1989) Moclobemide in the treatment of depression-an overview. Psychiatr Prax 16:37-40.

Laux G, Becker T and Müller U (2002) Monoamin-OxidaseHemmer. Klinik. In: Neuro-Psychopharmaka. (Riederer P, Laux G, Pöldinger W, eds). pp 489-518. Springer, Wien.

Laux G, Philipp M and Kohnen R (1996) Hypertension with moclobemide. Lancet 347:1330.

Laux G, Volz, HP and Müller HJ (1995) Newer and older monoamine oxidase inhibitors. A comparative profile. CNS Drugs 3:145-158.

Lees AJ, for the PDRG-UK (1995) Comparison of therapeutic effects and mortality data of levodopa and levodopa combined with selegiline in patients with early, mild Parkinson's disease. BMJ 311:1602-1607.

Levites Y, Amit T, Mandel S and Youdim MBH (2003) Neuroprotection and neurorescue against $\mathrm{A} \beta$ toxicity and PKC-dependent release of non-amyloidogenic soluble precursor protein by green tea polyphenol (-)-epigallocatehin3-gallate. FASEB J 17:952-954.

Lonnqvist J, Sihvo S, Syvalahti E, Sintonen H, Kiviruusu O and Pitkanen $H$ (1995) Moclobemide and fluoxetine in the prevention of relapses following acute treatment of depression. Acta Psychiatr Scand 91:189-194.

Magyar K, Szende B, Jenei V, Tabi T, Palfi M and Szökö E (2010) R-deprenyl: pharmacological spectrum of its activity. Neurochem Res 35:1922-1932.

Magyar K, Szende B, Lemgyel J and Tekes K (1996) The pharmacology of B-type selective monoamine oxidase inhibitors: milestones in (-)-deprenyl research. $J$ Neural Transm Suppl 48:29-43.

McDonald R and DeLong MR (2003) Prevalence, etiology, and treatment of depression in Parkinson's disease. Biol Psychiatry 54:363-375.

Mendlewicz J and Youdim MBH (1978) Anti-depressant potentiation of 5-hydroxytrytophan by I-deprenyl, a monoamine oxidase type B inhibitor. J Neural Transm 43:279-286.

Moll E, Neumann N, Schmid-Burgk W, Stabl M and Amrein R (1994) Safety and efficacy during long-term treatment with moclobemide. Clin Neuropharmacol 17:S74-87.

Montgomery EB and Panisset JM (2009) Retrospective statistical analysis of the incidence of serotonin toxicity in patients taking rasagiline and anti-depressants in clinical trials. Mov Dis 24:359.
Myllylä VV, Sotaniemi KA, Hakulinen P, Maki-lkola O and Heinonen EH (1997) Selegiline as the primary treatment of Parkinson's disease - a longterm double-blind study. Acta Neurol Scand 95:211-218.

Mytilineou C, Leonardi EK, Radcliffe P, Heinonen EH, Han SK, Werner P, Cohen G and Olanow CW (1998) Deprenyls and desmethylselegiline protect mesencephalic neurons from toxicity induced by glutathione depletion. J Pharmacol Exp Ther 284:700-706.

Nagahara AH, Merrill DA, Coppola G, Tsukada S, Schroeder BE, Shaked GM, Wang L, Blesch A, Kim A, Conner JM, Rockenstein E, Chao MV, Koo EH, Geschwind D, Masliah E, Chiba AA and Tuszynski MH (2009) Neuroprotective effects of brain -derived neurotrophic factor in rodent and primate models of Alzheimer's disease. Nat Med 15:331-337.

Naoi M and Maruyama W (2009) Functional mechanism of neuroprotection by inhibitors of type $B$ monoamine oxidase in Parkinson's disease. Expert Rev Neurother 9:1233-1250.

Naoi M and Maruyama W (2010) Monoamine oxidase inhibitors as neuroprotective agents in age-dependent neurodegenerative disorders. Curr Pharm Des 16:2799-2817.

Nardi AE, Lopes FL, Valenca AM, Freire RC, Nascimento I, Veras AB, Mezzasalma MA, de-Melo-Neto VL, SoaresFilho GL, King AL, Grivet LO, Rassi $A$ and Versiani $M$ (2010) Double-blind comparison of 30 and $60 \mathrm{mg}$ tranylcypromine daily in patients with panic disorder comorbid with social anxiety disorder. Psychiatry Res 175:260-265.

Neuvonen P, Pohjola-Sintonen S and Tacke U (1993) Five fatal cases of serotonin syndrome after moclobemidecitalopram or moclobemide-clomipramine overdoses. Lancet 342:1419.

Nolen W, Hoencamp I, Haffmans, PMJ (1994) Classical and selective monoamine oxidase inhibitors in refractory major depression. In: Refractory depression: current strategies and future directions. (Nolen W, Zohar, J, Roose SP, eds.), Wiley, New York.

Norman TR and Burrows GD (1995) A risk-benefit assessment of moclobemide in the treatment of depressive disorders. Drug Saf 12:46-54.

Olanow CW, Hauser RA, Jankovic J, Langston W, Lang A, Poewe W, Tolosa E, Stocchi F, Melamed E, Eyal E and Rascol O (2008) A randomized, double-blind, placebocontrolled, delayed start study to assess rasagiline as a disease modifying therapy in parkinson's disease (The ADAGIO study): rationale, design, and baseline characteristics. Mov Disord 23:2194-2201.

Olanow WC, Rascol O, Hauser R, Feigin PD, Jankovic J, Lang A, Langston W, Melamed E, Poewe W, Stocchi F, Tolosa E, for the ADABIO Study Investigators (2009) A double-blind, delayed-start trial of rasagiline in parkinson's disease. N Engl J Med 361:1268-1278.

Pannisset M, Schwied S, Ondo W (2007) Safety of concomitant therapy with rasagiline and antidepressants in parkinson's diesease. Mov Disord 22:340.

Pare C (1985) The present status of monoamine oxidase inhibitors. Br J Psychiatry 146:576-584.

Parkinson Study Group (2004) A controlled, randomized, delayed-start study of rasagiline in early Parkinson disease. Arch Neurol 61:561-566.

Parkinson Study Group (2002) A controlled trial of rasagiline in early Parkinson disease: the TEMPO Study. Arch Neurol 
59:1937-1943.

Parkinson Study Group (2005) A randomized placebo-controlled trial of rasagiline in levodopa-treated patients with Parkinson disease and motor fluctuations: the PRESTO study. Arch Neurol 62:241-248.

Parkinson study group (1989) Effect of deprenyl on the progression of disabilty in early Parkinson's disease. $N$ Engl J Med 321:1364-1371.

Parkinson Study Group (1993) Effects of tocopherol and deprenyl on the progression of disability in early Parkinson's disease. N Engl J Med 328:176-183.

Parkinson Study Group (1996b). Impact of deprenyl and tocopherol treatment on Parkinson's disease in DATATOP patients requiring levodopa. Ann Neurol 39:37-45.

Parkinson Study Group (1996a) Impact of deprenyl and tocopherol treatment on Parkinson's disease in DATATOP subjects not requiring levodopa. Ann Neurol 39:29-36.

Paykel ES (1995) Clinical efficacy of reversible and selective inhibitors of monoamine oxidase A in major depression. Acta Psychiatr Scand Suppl 386:22-27.

Philipp M, Delini-Stula A, Baier D, Kohnen R, Scholz $\mathrm{H}$ and Laux $G$ (1999) Assessment of sexual dysfunction in depressed patients and reporting attitudes in routine daily practice: results of the postmarketing observational studies with moclobemide, a reversible MAO-A inhibitor. Int $J$ Psychiatry Clin Practice 3:257-264.

Polasek TM, Elliot DJ, Somogyi AA, Gillam EM, Lewis BC and Miners JO (2006) An evaluation of potential mechanismbased inactivation of human drug metabolizing cytochromes P340 by monoamine oxidase inhibitors, including isoniazid. $\mathrm{Br} J$ Clin Pharmacol 61:570-584.

Rabey JM, Sagi I, Huberman M, Melamed E, Korczyn A, Giladi $\mathrm{N}$, Inzelberg R, Djaldetti R, Klein C and Berecz G Rasagiline Study Group (2000) Rasagiline mesylate, a new mao-b inhibitor for the treatment of parkinson's disease: a doubleblind study as adjunctive therapy to levodopa. Clin Neuropharmacol 23:324-330.

Rascol O (2005) Rasagiline in the pharmacotherapy of Parkinson's disease - a review. Expert Opin Pharmacother 6:2061-2075.

Rascol O, Brooks DJ, Melamed E, Oertel W, Poewe W, Stocchi F, Tolosa E, for the LARGO study group (2005) Rasagiline as an adjunct to levodopa in patients with Parkinson's disease and motor fluctuations (LARGO, Lasting effect in Adjunct therapy with Rasagiline Given Once daily, study): a randomised, double-blind, parallelgroup trial. Lancet 365:947-954.

Ravina B, Camicioli R, Como PG, Marsh L, Jankovic J, Weintraub D and Elm J (2007) The impact of depressive symptoms in early Parkinson disease. Neurology 69:342-347.

Reichmann H, Sommer U and Engfer A (2000) Nebenwirkungsprofil von Parkinson-Medikamenten. Thieme-Verlag, Stuttgart.

Reidenberg MM (1994) Abuse liability of I-deprenyl: examination of the clinical and preclinical pharmacological data. Clinic Pharmacol Therap 56:1-796.

Remick R, Froese C and Keller F (1989) Common side effects associated with monoamine oxidase inhibitors. Prog Neuropsychopharmacol Biol Psychiatry 13:497-504.

Reynolds GP, Riederer P, Sandler M, Jellinger $K$ and Seemann D (1978) Amphetamine and 2-phenylethylamine in post-mortem Parkinsonian brain after (-) deprenyl administration. J Neural Transm 43:271-277.

Richard IH, Kurlan R, Tanner C, Factor S, Hubble J, Suchowersky $O$ and Waters C (1997). Serotonin syndrome and the combined use of deprenyl and antidepressant in Parkinson's disease. Neurology 48:1070-1077.

Riederer P (2004) An interdisciplinary approach to the Understanding of normal Behaviour and neuropsychiatric Disorders in particular. In: Reflections on twentieth-century Psychopharmacology (Ban TA, Healy D, Shorter E, ed), p 319327. Vol. 4, Animula Publishing House, Budapest, Hungary.

Riederer P and Burger R (2009) Ist Schokolade ein psychopharmakon? Die rolle von $\beta$-Phenylethylamin als psychostimulus. PPT Heft 1:26-31.

Riederer P, Danielczyk W and Grünblatt E (2004) Monoamine oxidase-B inhibition in Alzheimer's diease. Neurotoxicology 25:271-277.

Riederer P, Konradi C, Schay $V$ et al (1987) Localization of MAO-A and MAO-B in human brain: a step in understanding the therapeutic action of -Deprenyl. Adv Neurol 45:111-118.

Riederer P and Lachenmayer L (2003) Selegiline's neuroprotective capacity revisited. J Neural Transm 110:1273-1278.

Riederer P, Lachenmayer L and Laux G (2004) Clinical applications of MAO-inhibitors Curr. Med Chem 11:20332043.

Riederer P and Youdim MBH (1986) Monoamine oxidase activity and monamine metabolism in brains of parkinsonian patients treated with I-deprenyl. J Neurochem 46:1359-1365.

Riederer $\mathrm{P}$, Youdim $\mathrm{MBH}$, Birkmayer $\mathrm{W}$ and Jellinger $\mathrm{K}$ (1978) Monoamine oxidase activity during (--)deprenyl therapy: human brain post-mortem studies. Adv Biochem Psychopharmacol 19:377-382.

Riederer P, Youdim MBH, Rausch WD, Birkmayer W, Jellinger K and Seemann D (1978) On the mode of action of L-deprenyl in the human central nervous system. J Neural Transm 43:217-226.

Robinson DS and Amsterdam JD (2008) The selegiline transdermal systemin major depressive disorder: a systematic review of safety and tolerability. J Affect Disord 105: 15-23.

Robinson DS, Gilmor ML, Yang Y, Moonsammy G, Azzaro AJ, Oren DA and Campbell BJ (2007) Treatment effects of selegiline transdermal system on symptoms of major depressive disorder: a meta-analysis of short-term, placebocontrolled, efficacy trials. Psychopharmacol Bull 40:15-28.

Sampaio C and Ferreira JJ (2010) ADAGIO trial hints that rasagiline slows disease progression. Nat Rev Neurol 6:126-128.

Sano I (1960) Biochemistry of the extrapyramidal system. Shinkei Kenkyu no Shimpo. Adv Neurol Sci 5:42.

Sano M, Ernesto C, Thomas RG et al (1997) A controlled trial of selegiline, alpha tocopherol, or both as treatment for Alzheimer disease. N Engl J Med 336:1216-1222.

Schapira A, Albrecht S, Barone P, Comella C, Hsu H, Massey D, et al., on behalf of the PROUD Study Group (2009) Immediate vs. delayed-start pramipexole in early Parkinson's disease: the PROUD study. Poster 1.278 on the 13th WFN World Congress on Parkinson's Disease and related disorders; Miami (VS) 13-15 December.

Schwarzschild MA (2010) Rasagiline in Parkinson's Disease. Letter to the editor. N Engl J Med 362:658. 
Shoulson I, Oakes D, Fahn S, Lang A, Langston JW, Kieburtz K, Rudolph A, and the Parkinson Study Group (2002) Impact of sustained deprenyl (selegiline) in levodopa-treated Parkinson's disease: a randomized placebocontrolled extension of the deprenyl and tocopherol antioxidative therapy in parkinsonism trial. Ann Neurol 51:604612.

Siderowf A and Stern M (2006) Clinical trials with rasagiline. Neurology 66:S80-S88.

Sterling J, Herzig Y, Goren T, Finkelstein N, Lerner D, Goldenberg W, Miskolczi I, Molnar S, Rantal F, Tamas T, Toth G, Zagyva A, Zekany A, Finberg J, Lavian G, Gross A, Friedman R, Razin M, Huang W, Krais B, Chorev M, Youdim MB and Weinstock M (2002) Novel dual inhibitors of AChE and MAO derived from hydroxy aminoindan and phenethlamine as potential treatment for Alzheimer's disease. J Med Chem 45:5260-5279.

Steur EN and Ballering LA (1997) Moclobemide and selegeline in the treatment of depression in Parkinson's disease. J Neurol Neurosurg Psychiatry 63:547

Szelenyi I, Editor. (1993) Inhibitors of monoamine oxidase B. Pharmacology and Clinical Use in Neurodegenerative Disorders. Birkhäuser Verlag; Basel/Switzerland.

Tariot PN, Cohen RM, Sunderland T, Newhouse PA, Yount D, Mellow AM, Weingartner $\mathrm{H}$, Mueller EA and Murphy $\mathrm{DL}$ (1987) L-deprenyl in Alzheimer's disease. Preliminary evidence for behavioral change with monoamine oxidase B inhibition. Arch Gen Psychiatry 44:427-433.

Thebault JJ, Guillaume M and Levy R (2004) Tolerability, safety, pharmacodynamics, and pharmacokinetics of rasagiline: a potent, selective, and irreversible monoamine oxidase type B inhibitor. Pharmacotherapy 24:1295-1305.

Thomas CE, Huber EW and Ohlweiler DF (1997) Hydroxyl and peroxyl radical trapping by the monoamine oxidase-B inhibitors deprenly and MDL 72,974A: implications for protection of biological substrates. Free Radic Biol Med 22:733-737.

Varga E and Tringer $L$ (1967) Clinical trial of a new type promptly acting psychoenergic agent (phenylisopropyl methylporpinyl-HC1, E-250). Acta Med Acad Shi Hung 23:189295.

Veazey C, Aki SO, Cook KF, Lai EC and Kunik ME (2005) Prevalence and treatment of depression in Parkinson's disease. J Neuropsychiatry Clin Neurosci 17:310-323.
Versiani M, Mardi A, Figueira I et al. (1990) Tolerability of moclobemide, a new reversible inhibitor of monoamine oxidaseA, compared with other antidepressants and placebo. Acta Psychiatr Scand Suppl 360:24-28.

Weinreb O, Amit T and Youdim MBH (2010) Rasagiline; a monoamine oxidase $B$ inhibitor and neuroprotective antiparkinson drug. Progress in Neurobiology 92:330-344.

Wermuth L and Bech P (2006) Depression in Parkinson's disease. A review. Acta Neurol Scand 114:360-380.

Yasar S, Justinova Z, Lee SH, Stefanski R, Goldberg SR and Tanda G (2006) Metabolic transformation plays a primary role in the psychostimulant-like discriminiative-stimulus effects of selegiline [(R)-(-)deprenyl]. J Pharmacol Exp Ther 317:387-394.

Yasar S, Winger G, Nickel B, Schulze G and Goldberg SR (1993) Preclinical Evaluation of I-Deprenyl: Lack of Amphetamine-Like Abuse Potential. In: Inhibitors of monoamine oxidase B. Pharmacology and Clinical Use in Neurodegenerative Disorders. (Szelanyi I, ed), pp 216-233. Birkhäuser Verlag, Basel/Switzerland.

Yogev-Falach $\mathrm{M}$, Amit $\mathrm{T}$, Bar-Am $\mathrm{O}$, Weinstock $\mathrm{M}$ and Youdim MB (2002) The involvement of mitorgen-activated protein (MAP) kinase in the regulation of amyloid precursor protein processing by novel cholinesterase inhibitors derived from rasagiline. FASEB $J$ 16:1674-1676.

Yogev-Falach M, Bar-Am O, Amit T, Weinstock $M$ and Youdim MB (2006) A multifunctional, neuroprotective drug, ladostigil (TV3326), regulates holo-APP translocation and processing. FASEB $J$ 20:2177-2179.

Youdim MB (2006) My love with monoamine oxidase, iron and Parkinson's disease. J Neural Transm Suppl 71:V-IX.

Youdim MB (2010) Rasagiline in Parkinson's Disease. Letter to the editor. N Engl J Med 362:657-658.

Youdim MB, Edmondson D and Tipton KF (2006) The therapeutic potential of monoamine oxidase inhibitors. Nat Rev Neurosci 7:295-309.

Youdim MBH and Tipton KF (2002) Rat striatal monoamine oxidase-B inhibiton by I-deprenyl and rasagiline: its relationship to 2-phenylethylamine-induced stereotypy and Parkinson's disease. Parkinsonism Relat Disord 8:247-253.

Zornberg GL, Bodkin JA and Cohen BM (1991) Severe adverse interaction between pethidine and selegiline. Lancet $337: 246$ 